\title{
Stan kadr administracji publicznej z perspektywy ogólnokrajowej i regionalnej
}

\section{Wprowadzenie}

W badaniach nad administracją publiczna, zwłaszcza w płaszczyźnie badawczej nauki administracji, ciągle aktualny pozostaje problem kadr administracyjnych. Do naszej świadomości dociera bowiem z coraz większą siłą refleksja, że wykonywanie zadań administracji publicznej następuje przez działanie osób w niej zatrudnionych, piastujących funkcje organów monokratycznych oraz uczestniczących w funkcjonowaniu organów kolegialnych, jak w samorządzie terytorialnym. O ile, oczywiście, wybór radnych organów stanowiących jednostek samorządu terytorialnego czy powoływanie, wybór bądź inna forma kreacji na stanowiska wojewodów czy ministrów jest wynikiem procesów demokratycznego kreowania organów władzy, gdzie pytanie o kwalifikacje zawodowe nie zawsze jest racjonalne (wyborcy nie zawsze kierują się kryterium fachowości), o tyle zatrudnienie w urzędach i jednostkach organizacyjnych, zwłaszcza na stanowiskach urzędniczych, winno być oparte na starannym doborze kandydatów do zatrudnienia.

Prowadząc rozważania na temat kadr administracyjnych, nie sposób nie odwołać się do cytatu z rozprawy T. Górzyńskiej: „Słuszne założenia teoretyczne, dobre prawo, przemyślane struktury i skrupulatnie opracowane metody pracy praktycznie mogą być dopiero naprawdę skuteczne, 
jeśli będą realizowane przez personel rozumiejący istotę i cele służby państwowej, przygotowany zawodowo i moralnie do powierzonych mu zadań"1. Podkreślić wypada datę sformułowania tej wypowiedzi - rok 1985 - a zatem ponad trzydzieści lat temu, gdy Polska należała do tzw. obozu państw demokracji ludowej i panował w niej ustrój socjalistyczny, bez względu na to, w jakim stopniu założenia tego ustroju były akceptowane przez obywateli, zważywszy na tradycję kultywowania przez społeczeństwo systemów wartości absolutnie przeciwstawnych wartościom tej ideologii. W tym czasie dobór kadr był podporządkowany również ideologicznym przesłankom² i wypowiedź T. Górzyńskiej wyraźnie odbiegała od obowiązujących stereotypów. Niestety, transformacja ustrojowa z początku lat dziewięćdziesiątych ubiegłego wieku w demokratyczne państwo prawa nie zdezaktualizowała w niczym jej słuszności i przydatności.

Skłania to, oczywiście, do pytań o przyczyny tego stanu rzeczy, zwłaszcza gdy wziąć pod uwagę obecny ustrój Polski jako demokratycznego państwa prawa, w którym względy ideologiczne winny ustąpić miejsca porządkowi prawnemu. Wydaje się, że przyczyny są dwojakiej natury: prawnej i socjologicznej. Pierwsza dotyczy stanu prawa regulującego zatrudnienie w administracji publicznej, druga zakorzenionych w mentalności społeczeństwa przekonań o przerostach biurokratycznych struktur i kadr administracyjnych. Obie są zaś wynikiem, mimo wszystko świadomych, działań osób czynnie zaangażowanych w kształtowanie polityki państwowej. Tak się jakoś bowiem złożyło, że w ciągu minionego ponad ćwierćwiecza funkcjonowania w Polsce demokratycznego ustroju albo decydenci polityczni nie zajmowali się stanem regulacji prawnej w ogóle³,

${ }^{1}$ T. Górzyńska, Stanowiska kierownicze w administracji państwowej. Zagadnienia prawne, Ossolineum, Warszawa 1985, s. 70.

${ }^{2} \mathrm{~W}$ przepisach ustaw stanowiących podstawy zatrudnienia w ówczesnej administracji państwowej dominowały takie kryteria, jak rękojmia należytego wykonywania zadań pracownika ze względu na poziom ideowo-moralny, zob. art. 11 ust. 1 pkt 4 Ustawy z dnia 15 VII 1968 r. o pracownikach rad narodowych (Dz.U. Nr 25, poz. 164), również § 2 Rozporządzenia Rady Ministrów z dnia 20 XII 1974 r. w sprawie praw i obowiązków pracowników urzędów państwowych (Dz.U. Nr 49, poz. 300), w nieco tylko zmienionej treści art. 3 pkt 4 Ustawy z dnia 16 IX 1982 r. o pracownikach urzędów państwowych (tekst jedn. Dz.U. 2013, poz. 269).

${ }^{3}$ Przykładem jest Ustawa z dnia 16 IX 1982 r. o pracownikach urzędów państwowych (tekst jedn. Dz.U. 2016, poz. 1511), która mimo archaizmu użytych w niej terminów, często nieodnoszących się już w ogóle do istniejących organów i urzędów administracji publicznej, w znacznej części martwa i niewykonywana, mimo oczywistej potrzeby nowoczesnego uregulowania zatrudnienia urzędników państwowych - poza 
albo była ona przedmiotem poważnych sporów politycznych ${ }^{4}$, albo wręcz narzędziem realizacji doraźnych celów politycznych ${ }^{5}$.

\section{Charakterystyka polskiego prawa urzędniczego}

Przede wszystkim podkreślić należy, że Polska po II wojnie światowej nie wróciła już nigdy do modelu prawa urzędniczego, który jest rozpowszechniony w Europie. Jest to model kariery służbowej traktujący prawo urzędnicze jako prawo administracji publicznej, w którym występuje korpusowy system organizacji kadr administracyjnych. Zarazem nie przyjęła anglosaskiego modelu zatrudnienia pozycyjnego, ale wykształciła własny model pośredni między dwoma dotychczasowymi. Skutkiem tego jest traktowanie prawa urzędniczego jako części prawa pracy, co prawda, bez podporządkowania generalnemu aktowi, jakim jest Kodeks pracy ${ }^{6}$, ale za to $z$ licznymi, rozproszonymi i niekompletnymi regulacyjnie pragmatykami urzędniczymi. Czyni to z nich akty niesamodzielne, bowiem każda z pragmatyk w jakiejś części spraw zatrudnienia urzędników wymaga zastosowania albo przepisów Kodeksu pracy, albo innych ustaw administracyjnego prawa ustrojowego ${ }^{7}$ lub

fragmentarycznymi nowelizacjami nie została zastąpiona współczesną kompleksową regulacją prawną.

${ }^{4}$ Prawie sześć lat zajęło politykom ustalenie kształtu polskiej służby cywilnej i mimo podjętych już w 1990 r. przygotowań dopiero 5 VII 1996 r. uchwalono ustawę o służbie cywilnej, która zaledwie zaczęła obowiązywać, została natychmiast zastąpiona nową ze względu na skandal polityczny związany z niezgodnymi z jej przepisami powołaniami dyrektorów generalnych urzędów administracji rządowej. Zob. na ten temat J. Korczak, Kadry administracji publicznej wobec przeobrażeń we wspótczesnym prawie administracyjnym, w: Wspótczesne problemy administracji publicznej i prawa administracyjnego. Materiaty z sesji naukowej na temat przeobrażeń we wspótczesnym prawie administracyjnym - Wrocław, listopad 1997, pod red. A. Błasia, Wrocław-Poznań 1999, s. 43-56.

${ }^{5}$ Przykładem tego jest nowelizacja ustawy o służbie cywilnej z grudnia 2015 r. Ustawa z dnia 30 XII 2015 r. o zmianie ustawy o służbie cywilnej oraz niektórych innych ustaw (Dz.U. 2016, poz. 34), która miała na celu pozbycie się z urzędów rządowej administracji osób zajmujących wyższe stanowiska w służbie cywilnej, które zostały na nie przeniesione w okresie poprzednim, tj. za rządów obecnej opozycji. Zob. na ten temat J. Korczak, Antywartość w prawie administracyjnym jako zamierzony skutek legislacyjny, w: Antywartość w prawie administracyjnym, pod red. A. Błasia, Warszawa 2016.

${ }^{6}$ Ustawa z dnia 26 VI 1974 r. - Kodeks pracy (tekst jedn. Dz.U. 2016, poz. 1666), dalej „k.p.".

${ }^{7}$ Przykładowo, status burmistrza miasta w Polsce regulują aż trzy ustawy: Ustawa z dnia 21 XI 2008 r. o pracownikach samorządowych (tekst jedn. Dz.U. 2016, poz. 902), czyli samorządowa pragmatyka urzędnicza, Ustawa z dnia 8 III 1990 r. o samorządzie 
materialnego ${ }^{8}$. Do tego należy wziąć pod uwagę ustrój administracji publicznej, który mimo unitarnego charakteru państwa, dzieli ją na trzy zasadnicze sektory: administrację państwową, scentralizowaną administrację rządową i administrację zdecentralizowana, która dodatkowo dzieli się na administrację samorządu terytorialnego oraz samorządów: gospodarczego i zawodowych. Administracja państwowa nie jest powiązana z rządem, co najwyżej podlega kontroli parlamentarnej', ale przy tym nie ma wspólnego zwierzchnika, co powoduje, że każdy jej organ ma osobną regulację prawna, a tylko w niewielkim stopniu zastosowanie mają do zatrudnionych przepisy wspomnianej już ustawy o pracownikach urzędów państwowych. Administracja rządowa, mimo scentralizowania pod zwierzchnictwem Prezesa Rady Ministrów, jest jednak wewnętrznie zróżnicowana, bowiem obok zatrudnionych na stanowiskach urzędniczych w ramach stosunków pracy występują tu funkcjonariusze zatrudnieni w ramach stosunków służbowych ${ }^{10}$, ponadto sama grupa zatrudnionych $\mathrm{w}$ ramach stosunku pracy jest podzielona na korpus służby cywilnej i korpus służby zagranicznej, wreszcie w samym korpusie służby cywilnej występuje zróżnicowanie związane z przynależnością do organów administracji zespolonej pod zwierzchnictwem wojewodów oraz niezespolonej. Cechą administracji samorządu terytorialnego jest przede wszystkim niezależność gmin, powiatów i województw od siebie, a tym samym zatrudnienie odbywa się na obszarze danej jednostki, choć przepisy pragmatyki samorządowej pozwalają na przenoszenie urzędników między jednostkami za porozumieniem kierowników poszczególnych jednostek organizacyjnych. W przypadku

gminnym (tekst jedn. Dz.U. 2016, poz. 446 ze zm.), czyli ustawa ustrojowa, a także Ustawa z dnia 5 I 2011 r. - Kodeks wyborczy (Dz.U. Nr 21, poz. 112 ze zm.), czyli ordynacja wyborcza.

${ }^{8}$ Przykładowo, status powiatowego inspektora nadzoru budowlanego reguluje Ustawa z dnia 21 XI 2008 r. o służbie cywilnej (tekst jedn. Dz.U. 2016, poz. 1345 ze zm.), czyli pragmatyka urzędnicza, a także Ustawa z dnia 7 VII 1994 r. - Prawo budowlane (tekst jedn. Dz.U. 2016, poz. 290), czyli ustawa prawa materialnego; z kolei status wojewódzkiego konserwatora zabytków reguluje również pragmatyka urzędnicza - ustawa o służbie cywilnej - oraz prawo materialne - Ustawa z dnia 23 VII 2003 r. o ochronie zabytków i opiece nad zabytkami (tekst jedn. Dz.U. 2014, poz. 1446 ze zm.).

${ }^{9}$ Przykładowo, Generalny Inspektor Ochrony Danych Osobowych czy Rzecznik Praw Obywatelskich.

${ }^{10}$ Przykładowo, funkcjonariusze Policji, Państwowej Straży Pożarnej, Straży Granicznej, Służby Więziennej oraz służb specjalnych: Centralnego Biura Antykorupcyjnego, Agencji Bezpieczeństwa Wewnętrznego, Agencji Wywiadu, Służby Wywiadu Wojskowego i Służby Kontrwywiadu Wojskowego itd. 
administracji samorządów gospodarczego i zawodowych nie występują z kolei stanowiska urzędnicze, a funkcje w organach samorządów sprawowane są bez nawiązywania stosunków pracy.

W odróżnieniu od tradycyjnego modelu kariery służbowej, gdzie $\mathrm{z}$ racji publicznoprawnego charakteru stanowiska urzędniczego zatrudnienie następowało głównie na podstawie aktu mianowania, polski model prawa urzędniczego cechuje wielość form prawnych nawiązywania stosunków pracy, jedynie stosunki służbowe nawiązywane są na podstawie aktów mianowania i aktów powołania. W przypadku urzędników zatrudnianych w ramach stosunku pracy stosowane są akty wyboru $^{11}$, akty powołania ${ }^{12}$, akty mianowania ${ }^{13}$ oraz umowy o pracę $^{14}$. Należy zwrócić uwagę, że odpowiednie regulacje Kodeksu cywilnego wprowadzają domniemanie umowy o pracę jako formy nawiązania stosunku pracy, zaś wobec pozostałych aktów wymagane jest wskazanie każdego $\mathrm{z}$ nich $\mathrm{w}$ danej pragmatyce ${ }^{15}$, co powoduje, iż wśród zatrudnionych w administracji publicznej ogółem (bez uwzględnienia opisywanych wcześniej dyferencjacji) grupa zatrudnionych na podstawie umowy o pracę przeważa bezwzględnie nad pozostałymi grupami wyróżnianymi ze względu na formę ich zatrudnienia. Przy tym jedynie w korpusie służby cywilnej zagwarantowane jest przejście członka korpusu z kategorii zatrudnionych na podstawie umowy o pracę do

${ }^{11}$ Na podstawie aktu wyboru zatrudniani są: wójtowie gmin, burmistrzowie i prezydenci miast, starostowie i pozostali członkowie zarządów powiatów oraz marszałkowie i pozostali członkowie zarządów województw.

12 Stosowane do obsadzania stanowisk kierowników centralnych urzędów administracji rządowej czy wojewodów, ale też skarbników gmin, powiatów i województw oraz zastępców wójtów gmin, burmistrzów i prezydentów miast.

${ }^{13} \mathrm{Z}$ rzadka niektórych urzędników państwowych, ale przede wszystkim urzędników służby cywilnej, natomiast od 2009 r. nie ma już urzędników mianowanych w samorządzie terytorialnym.

${ }^{14}$ Zasadniczo jest to forma dominująca w urzędach administracji państwowej, rządowej (członkowie korpusu niebędący urzędnikami służby cywilnej) i samorządowej.

${ }^{15}$ Przepis art. $68 \S 1$ k.p. stanowi, że stosunek pracy nawiązuje się na podstawie powołania w przypadkach określonych w odrębnych przepisach i tak stanowi art. 4 ust. 1 pkt 2 pragmatyki samorządowej. Przepis art. $73 \S 1$ k.p. stanowi, że nawiązanie stosunku pracy na podstawie wyboru następuje wówczas, gdy z wyboru wynika obowiązek wykonywania pracy w charakterze pracownika i z tego powodu art. 4 ust. 1 pkt 1 pragmatyki samorządowej wymienia wspomnianych już piastunów organów wykonawczych jednostek samorządu terytorialnego jako samorządowych pracowników zatrudnianych na podstawie wyboru. Z kolei przepis art. 76 k.p. stanowi, że stosunek pracy nawiązuje się na podstawie mianowania w przypadkach określonych w odrębnych przepisach i takim przepisem jest art. 3 pkt $2 \mathrm{w}$ zw. z art. 49 pragmatyki służby cywilnej. 
kategorii mianowanych urzędników służby cywilnej w wyniku pomyślnego przejścia odpowiedniego postępowania kwalifikacyjnego ${ }^{16}$, podczas gdy u pracowników samorządowych, mimo przewidzianego art. 20 pragmatyki samorządowej awansu wewnętrznego, co może polegać na przejściu ze stanowiska urzędniczego na kierownicze urzędnicze, nie musi to pociągać za sobą zmiany formy nawiązania stosunku pracy, jako że obie kategorie stanowisk objęte są tą samą formą zatrudnienia.

Tak scharakteryzowany stan regulacji polskiego prawa urzędniczego nie sprzyja należytemu doborowi kadr i ich późniejszemu rozwojowi, zwłaszcza gdy nakładają się na to względy natury politycznej oraz nieuniknione zjawiska patologiczne (nepotyzm, nieuczciwość członków zespołów przeprowadzających nabory na wolne stanowiska). Na te jego negatywne cechy nakładają się wspomniane na wstępie uwarunkowania socjologiczne, których ogólny wydźwięk to krytyczny stosunek do administracji jako takiej, a do jej przedstawicieli - urzędników i funkcjonariuszy piastujących stanowiska organów administracji publicznej w szczególności. Nie budzą oni zaufania w społeczeństwie ${ }^{17}$, a przy tym są często wykorzystywani przez polityków jako odpowiedzialni za niepowodzenia politycznych programów i inicjatyw, bez względu na to, czy rzeczywiście pojedynczy urzędnik jest w stanie uniemożliwić ich realizację lub też naprawić błędy polityków.

\section{Analiza danych dotyczących stanu zatrudnienia oraz struktur demograficznych kadr administracji publicznej w ujęciu ogólnopolskim}

Na temat liczby zatrudnionych w administracji publicznej w Polsce, podobnie jak w innych państwach, trwa spór między tymi, którzy uważaja, że liczba ta jest za duża, i co więcej, stale wzrasta, a tymi, którzy uważaja, że liczba nie jest adekwatna do potrzeb społecznych, co przejawia się oczekiwaniem w kolejce osób chcących załatwić swoje sprawy w urzędzie, a następnie równie długo oczekujących na formalne zakończenie postępowania $w$ tych sprawach. Spór jest $\mathrm{z}$ gatunku nierozwiązywalnych, bowiem nie istnieją odpowiednio ustalone metodologie badań

\footnotetext{
${ }^{16}$ Zob. art. 40-51 pragmatyki służby cywilnej.

${ }^{17} \mathrm{Na}$ ten temat zob. J. Korczak, Pozyskiwanie i umacnianie zaufania do władz publicznych przez współadministrowanie, w: Sprawiedliwość i zaufanie do władz publicznych w prawie administracyjnym, pod red. M. Stahl, M. Kasińskiego, K. Wlaźlak, Warszawa 2015, s. 98-114.
} 
statystycznych pozwalające w sposób jednoznaczny obliczyć liczbę osób zatrudnionych w administracji publicznej na stanowiskach urzędniczych, skoro brak jest obiektywnych kryteriów ich wydzielenia, jako że każda ustawa z zakresu prawa urzędniczego posługuje się inną klasyfikacją stanowisk. Najczęściej zatem Główny Urząd Statystyczny (GUS) podaje dane o stanie zatrudnienia w sektorze publicznym, a następnie liczby zatrudnionych w poszczególnych sektorach administracji: państwowej, rządowej i samorządu terytorialnego, ale dane te nie są mimo to precyzyjne. $Z$ kolei zarzucający przerosty zatrudnienia używają terminu "urzędnik" na określenie każdego zatrudnionego w administracji publicznej, gdzie przecież oprócz osób zatrudnionych na stanowiskach urzędniczych spotykamy osoby na stanowiskach obsługowych zajmujące się choćby utrzymaniem zieleni miejskiej czy usługą pochówku zmarłych.

W 2014 r. liczba osób zatrudnionych w całym sektorze publicznym sięgała $3 \mathrm{mln}$, zaś w administracji rządowej i państwowej przekroczyła 440 tys. osób, w samorządzie terytorialnym 260 tys. osób. Takie dane zestawia się z rokiem 1989, a zatem rokiem początku transformacji ustrojowej, kiedy w urzędach administracji państwowej zatrudnionych było 160 tys. osób. Jest to zestawienie o tyle błędne, że po pierwsze, wszelkie dane statystyczne $\mathrm{z}$ okresu państwa socjalistycznego są niewiarygodne, po drugie, nie bierze się pod uwagę odmienności samego ustroju administracji publicznej, który wówczas był jednolity i scentralizowany, dzisiaj zaś jest zdecentralizowany, po trzecie, nie bierze się pod uwagę tego, że nastąpił wzrost sfery usług publicznych, bo pojawiły się nowe potrzeby społeczne będące konsekwencją nowych rozwiązań technicznych, wreszcie po czwarte, nie bierze się pod uwagę, że część zadań współczesnej administracji wykonywały przedsiębiorstwa tzw. użyteczności publicznej niezaliczane wówczas do administracji państwowej. Publicyści i inni uczestnicy debat publicznych na temat stanu administracji w Polsce podają przykłady innych państw europejskich, gdzie zatrudnienie $w$ administracji publicznej spadło o ok. 800 tys. w skali Unii Europejskiej w ciągu kilku ostatnich lat, choć nie podają źródeł pochodzenia tych danych oraz metodyki ich agregacji. W Polsce obserwujemy bardzo zróżnicowane procesy zmian w stanie zatrudnienia, bowiem $z$ jednej strony spada zatrudnienie $w$ administracji rządowej, z drugiej zaś, wzrasta w administracji samorządowej, i tym samym nie można jednoznacznie oceniać tego zjawiska.

Należy wziąć pod uwagę liczbę urzędów administracji publicznej jako potencjalnych pracodawców urzędników, ta zaś jest pochodną regulacji 
prawnych powołujących poszczególne organy administracji i obsługujące je urzędy (wbrew głoszonym niekiedy poglądom urzędów nie tworzy się dowolnie i nie jest to proces żywiołowy). Na poziomie centralnym państwa występują 24 ministerstwa ${ }^{18}$ oraz ponad 80 urzędów państwowych i rządowych ${ }^{19}$, na poziomie województw występuje 16 urzędów wojewódzkich i odpowiednia liczba urzędów terenowych organów w pionach organów centralnych mających swoje struktury terytorialne, a ponadto występują już także urzędy samorządowe (16 urzędów marszałkowskich), wreszcie na poziomie powiatów, oprócz 314 starostw, istnieje odpowiednia do nich liczb powiatowych organów administracji rządowej zespolonych pod starostą i niezespolonych (powiatowi lekarze weterynarii), na koniec w 2478 gminach występują urzędy gmin i miast. Jeśli do tego prostego schematu terytorialno-ustrojowego dodamy organy o nietypowych strukturach terytorialnych (np. urzędy morskie, urzędy górnicze itp.), to liczba kilku tysięcy urzędów nie wydaje się ani przesadna, ani niczym nieuzasadniona, należy jednak wziąć pod uwagę, że obok klasycznego urzędu administracyjnego w administracji występuje wiele jednostek organizacyjnych, w których także są zatrudnieni na stanowiskach urzędniczych. Zatrudnienie w tych urzędach nie jest wartością stała, bowiem obok naturalnej fluktuacji, obserwujemy stały spadek zatrudnienia $\mathrm{w}$ administracji rządowej przy jednoczesnym wzroście jego stanu w administracji samorządowej. Jednak i fluktuacja, i szereg innych procesów zachodzących w stanie kadr budzi wątpliwości co do ich wpływu na sprawność funkcjonowania administracji publicznej.

\section{Analiza danych dotyczących stanu zatrudnienia oraz struktur demograficznych kadr administracji publicznej w administracji rządowej i państwowej stopnia centralnego}

Analiza danych udostępnionych przez GUS oraz Szefa Służby Cywilnej ${ }^{20}$ potwierdza spadek zatrudnienia ogółem w administracji państwowej i rządowej. Tylko w korpusie służby cywilnej od 2010 r. ubyło ponad

${ }^{18}$ Ich liczba jest zależna od rozporządzeń wydanych przez Prezesa Rady Ministrów na podstawie art. 33 ust. 1 Ustawy z dnia 8 VIII 1996 r. o Radzie Ministrów (tekst. jedn. Dz.U. 2012, poz. 392 ze zm.).

${ }^{19}$ Każdy z nich ma osobną podstawę ustawową.

${ }^{20}$ Podczas przygotowania artykułu korzystano $z$ danych zamieszczonych na stronie internetowej Serwisu Służby Cywilnej: https://dsc.kprm.gov.pl (dostęp: 18 X 2016). 
3,7 tys. członków. Jednocześnie ogólna liczba etatów urzędniczych spadła o 1155 i na koniec 2015 r. wynosiła 119,3 tys.; aż 38\% urzędów dokonało zmniejszenia zatrudnienia, w samej tylko administracji skarbowej spadek sięgnął 748 etatów. Kolejnym zjawiskiem jest fluktuacja, która tylko w 2015 r. wyniosła 7,3\%, ale w niektórych urzędach sięgała ponad $20 \%$.

Obserwowany jest równolegle spadek atrakcyjności zatrudnienia w korpusie służby cywilnej, co pokazuje, że praca w tej z założenia elitarnej kadrze urzędniczej nie jest wcale atrakcyjna. W 2015 r. odnotowano kolejny spadek liczby zgłoszeń na jedno wakujące stanowisko do średnio 19 kandydatów, podczas gdy w 2013 r. było 36, a w 2014 r. 24 kandydatów. Coraz mniejsza atrakcyjność zatrudnienia na stanowiskach urzędniczych w administracji rządowej powoduje też spadek liczby osób młodych, tj. do 30. roku życia (10,4\% w 2014 r. do 9\% w 2015 r.), zdecydowanie rośnie liczba osób w przedziale 31-50 lat (z 57,4\% w 2014 r. do 59\% w 2015 r.), w przedziale 51-55 lat uległ obniżeniu o $1 \%$ do poziomu 30,8\%, a nie uległ zmianie w kategorii ponad 65 lat i wynosi 1,2\%. Mimo tych trendów w 2015 r. 5 tys. osób podjęło zatrudnienie po raz pierwszy na stanowisku urzędniczym, stanowiąc $73 \%$ osób zatrudnionych na wolnych stanowiskach w wyniku naboru, co oznacza istotny wzrost w porównaniu $z$ latami ubiegłymi.

Ponadto pogarsza się struktura zatrudnionych w korpusie, gdy idzie o proporcje między członkami a urzędnikami służby cywilnej. Jak wspomniano, korpus zgodnie $\mathrm{z}$ art. 3 ustawy dzieli się zasadniczo na dwie kategorie osób zatrudnionych na stanowiskach urzędniczych: pracowników służby cywilnej zatrudnionych na podstawie umowy o pracę i mianowanych urzędników służby cywilnej. Ze względu na utrzymywany od kilku lat niski limit mianowanych liczba urzędników nie przekracza 6,5\% ogółu członków korpusu (7745 etatów). Z ogólnej liczby 119 tys. zatrudnionych na stanowiskach urzędniczych 12345 to urzędnicy ministerstw (choć spośród nich tylko 2517 to urzędnicy mianowani), 10926 urzędów centralnych (tu 625 mianowanych), 8578 urzędów wojewódzkich (wśród nich 642 mianowanych), 14823 administracji zespolonej w województwie (z 203 mianowanymi), 8615 administracji zespolonej w powiecie (tu zaledwie 22 mianowanych urzędników), 40920 administracji skarbowej (z 2150 mianowanymi urzędnikami) i 4963 w urzędach kontroli skarbowej (spośród nich 924 mianowanych), w pozostałej administracji niezespolonej zatrudnionych było 16842 urzędników (w tym 351 urzędników mianowanych) i w korpusie zagranicznym 1245 
(z 311 mianowanymi). O mianowaniu na urzędnika służby cywilnej decyduje przede wszystkim limit ustalany w ustawie budżetowej na dany rok, co w 2015 r. oznaczało 200 osób. Zgłosiło się 36 absolwentów Krajowej Szkoły Administracji Publicznej, którzy zostali mianowani w trybie ustawowym, a także 828 osób (w 2014 r. - 880), z których 291 zakończyło postępowanie kwalifikacyjne z wynikiem pozytywnym, co doprowadziło do ostatecznego mianowania spośród nich 162 osób (to oznacza, że nie obsadzono dwóch mianowanych stanowisk urzędniczych).

Pogarsza się również struktura zatrudnienia pod względem płci. Korpus jest sfeminizowany $-70 \%$ zatrudnionych w korpusie to kobiety. Także w kategorii wyższych stanowisk kobiety zajmują 53\% z nich.

Mimo przepisów zachęcających do zatrudnienia osób niepełnosprawnych w dalszym ciągu wskaźnik ich zatrudnienia jest niski i sięga 3,9\%. Jednak istnieją pojedyncze urzędy, w których przekracza on nawet $12 \%$.

Kiedy w 2009 r. w art. 4 ustawy o służbie cywilnej dokonano zastrzeżenia, że wymóg posiadania obywatelstwa polskiego do członkostwa $\mathrm{w}$ korpusie nie jest bezwzględny ${ }^{21}$, bowiem w art. 5 przewidziano możliwość zatrudnienia na wskazanych przez dyrektora generalnego urzędu stanowiskach urzędniczych obywateli państw członkowskich Unii Europejskiej oraz innych państw, z którymi Polska ma zawarte stosowne umowy bilateralne, oczekiwano napływu członków korpusu z tych państw. W 2015 r. rzeczywiście dziesięciu obcokrajowców złożyło swoje oferty do naborów na wolne stanowiska urzędnicze, ale tylko jeden $\mathrm{z}$ nich został zatrudniony.

${ }^{21}$ Przepis art. 4 pragmatyki służby cywilnej zawiera katalog podstawowych wymagań kwalifikacyjnych, których spełnienie formalnie dopuszcza do udziału w naborze na wolne stanowisko urzędnicze bez przesądzania o jego wyniku, ale też wymagania te muszą być spełnione przez późniejszego członka korpusu w ciągu całego okresu zatrudnienia, bowiem zaprzestanie spełniania któregokolwiek z nich powoduje ustanie zatrudnienia, w zależności od wymogu i charakteru członkostwa w drodze wygaśnięcia, rozwiązania stosunku pracy bez wypowiedzenia lub za wypowiedzeniem obligatoryjnym. Wymóg posiadania obywatelstwa wymieniony jest $\mathrm{w}$ punkcie pierwszym $\mathrm{z}$ zastrzeżeniem zastosowania art. 5, który dopuszcza wyznaczenie przez dyrektora generalnego urzędu stanowiska urzędniczego, na którym może zostać zatrudniony obywatel UE lub innego państwa, z którym Polska ma zawarte odpowiednie umowy międzynarodowe, niebędący jednocześnie obywatelem polskim, pod warunkiem potwierdzenia dobrej znajomości języka polskiego. Przepis art. 5 w ust. 2 wyłącza z zakresu stanowisk możliwych do objęcia przez obcokrajowców te, które są związane z wykonywaniem władzy publicznej i ochroną generalnych interesów państwa. 


\section{Analiza danych dotyczących stanu zatrudnienia oraz struktur demograficznych kadr administracji publicznej na Dolnym Śląsku}

Na tle tych danych ogólnopolskich sytuacja dolnośląska nie odbiega od pewnych trendów obserwowanych w pozostałych regionach. Należy przypomnieć, że w województwie funkcjonuje administracja rządowa na poziomie wyłącznie województwa i powiatu równolegle $\mathrm{z}$ wojewódzkim i powiatowym samorządem, natomiast w gminach funkcjonuje już tylko samorząd gminny, stąd też zatrudnienie w administracji publicznej dotyczyć będzie zatrudnienia w urzędach i jednostkach organizacyjnych administracji rządowej oraz w urzędach i jednostkach organizacyjnych samorządu terytorialnego.

Na terenie województwa istnieje 26 powiatów oraz 4 miasta na prawach powiatu (Wrocław, Wałbrzych, Legnica i Jelenia Góra). W tej strukturze terytorialnej funkcjonuje w administracji rządowej jeden Dolnośląski Urząd Wojewódzki wraz z trzema jego delegaturami (w Wałbrzychu, Legnicy i Jeleniej Górze) i odpowiednio komendy wojewódzkie Policji i Państwowej Straży Pożarnej, wojewódzkie inspekcje, izby: skarbowa i celna, ponadto delegatury i oddziały centralnych urzędów państwowych (np. Najwyższej Izby Kontroli, Państwowej Inspekcji Pracy); również na poziomie powiatu funkcjonują odpowiednio powiatowe komendy, inspekcje i straże, ale też 34 urzędy skarbowe. Jeśli zaś chodzi o administrację samorządową, to oczywiste jest, że należy uwzględnić jeden Urząd Marszałkowski Województwa Dolnośląskiego z wieloma jednostkami organizacyjnymi ${ }^{22}, 26$ starostw i 169 urzędów miast i gmin.

W tych urzędach i jednostkach organizacyjnych w 2015 r. zatrudnionych było ogółem 46065 osób, co w stosunku do 2005 r., kiedy zatrudnienie wynosiło 41701 osób, oznacza wzrost o 10,5\%. W tej liczbie w administracji państwowej zatrudnionych było 14435 osób, w administracji rządowej 11040 osób, a w administracji samorządowej 20582

${ }^{22}$ Wykaz zamieszczony w Biuletynie Informacji Publicznej obejmuje Dolnośląski Zespół Parków Krajobrazowych, Dolnośląską Służbę Dróg i Kolei, Dolnośląski Zarząd Melioracji i Urządzeń Wodnych, Instytut Rozwoju Terytorialnego, Dolnośląskie Biuro Geodezji i Terenów Rolnych, Regionalne Biuro Województwa Dolnośląskiego w Brukseli, Dolnośląski Wojewódzki Urząd Pracy w Wałbrzychu, Dolnośląski Ośrodek Polityki Społecznej, Dolnośląską Instytucję Pośrednicząca, cztery wojewódzkie ośrodki ruchu drogowego, Dolnośląski Ośrodek Doradztwa Rolniczego, a ponadto trzynaście szkół, sześć bibliotek pedagogicznych, cztery ośrodki kształcenia nauczycieli, cztery ośrodki wychowawcze, siedemnaście instytucji kultury i kilkanaście podmiotów leczniczych. 
osoby. W każdym z sektorów dolnośląskiej administracji publicznej obserwuje się inną dynamikę zmian stanu zatrudnienia, bowiem o ile $\mathrm{w}$ administracji państwowej zasadniczo liczba zatrudnionych nie uległa znaczącym zmianom, o tyle w administracji rządowej w ciągu ostatnich pięciu lat nastąpił spadek o 7\%, a w administracji samorządowej wzrost o $3 \%$, przy czym w powiatach nastąpił spadek o blisko $5 \%$, podczas gdy w województwie wzrost o $20 \%$.

Jednak dopiero bardziej szczegółowa analiza danych statystycznych ukazuje pełny obraz procesów zachodzących w stanie kadr dolnośląskich. Potwierdza się problem spadku atrakcyjności zatrudnienia w administracji, bowiem jeżeli w 2005 r. przyjęto 7884 pracowników, to w 2015 r. już tylko 5382; należy przy tym zauważyć, że w liczbie przyjętych przeważała grupa osób już wcześniej zatrudnionych, skoro jedynie $665 \mathrm{z}$ nich były to osoby podejmujące pracę po raz pierwszy, z czego 383 osoby były absolwentami szkół wyższych.

Jeśli zestawić tę ostatnią liczbę z danymi o kończących corocznie szkoły wyższe na terenie Dolnego Śląska, to wynik tego zestawienia jest niepokojący. Skłania on do analizy struktury zatrudnienia $\mathrm{w}$ administracji publicznej pod względem poziomu zatrudnienia. Zgodnie z danymi udostępnionymi przez Urząd Statystyczny we Wrocławiu za rok $2014 \mathrm{w}$ administracji dolnośląskiej pracowały 344 osoby ze stopniem naukowym doktora lub wyższym, natomiast z tytułem zawodowym magistra lub równorzędnym zatrudnionych było 18918 osób, zaś z tytułem inżyniera lub licencjata 3928 osób. W tym samym okresie zatrudnionych było w administracji 1527 osób z wykształceniem policealnym, 4678 ze średnim zawodowym i 17772 ze średnim ogólnokształcącym. Poza stanowiskami urzędniczymi na stanowiskach pomocniczych i obsługi zatrudnionych było 1337 osób z wykształceniem zawodowym oraz 521 z wykształceniem gimnazjalnym oraz podstawowym i niepełnym podstawowym. Należy pamiętać, że na stanowiskach urzędniczych nie mogą być zatrudnione osoby poniżej wykształcenia średniego, zawodowego lub ogólnokształcącego.

Potwierdza się też problem feminizacji kadr, bowiem na ogólną liczbę 46 tys. zatrudnionych aż 66,1\% stanowiły kobiety. Kobiety przeważały także pośród nowo zatrudnionych w 2015 r. - 58,9\%, pośród podejmujących pracę po raz pierwszy - ok. $60 \%$, a wśród nich absolwentki szkół wyższych - 73\%.

Opisane wyżej procesy: malejącej atrakcyjności zatrudnienia w administracji, spadku liczby absolwentów podejmujących pierwsze po 
ukończeniu studiów zatrudnienie w administracji, wpływają także na strukturę grup wiekowych dolnośląskich urzędników. Zgodnie z danymi udostępnionymi przez Urząd Statystyczny we Wrocławiu na koniec 2014 r. najliczniejszą grupą byli urzędnicy w przedziale 55-59 lat (5676), następną w przedziale 35-39 lat (5250), po niej w przedziale 30-34 lata (4850), następną w wieku 40-44 lata (4469) i 50-54 lata (4360), po nich grupa wiekowa 45-49 lat (3646) i dwie grupy: 25-29 lat (2128) oraz 60-64 lata (2059). Natomiast najmniej liczne były dwie grupy wiekowo skrajne: 20-24 lata (323) i powyżej 65. roku życia (264).

Poruszane zagadnienie fluktuacji, w skali kraju sygnalizowane jako przejaw słabości ustawodawstwa, które nie wiąże urzędnika $\mathrm{z}$ administracją na całe niemal życie zawodowe, jak to miało miejsce u początków prawa urzędniczego w pruskim modelu kariery zawodowej, obserwowane jest także na Dolnym Śląsku. W 2015 r. doszło do ustania stosunków pracy 8806 urzędników (w tej liczbie 3187 kobiet). Jeśli przypomnieć, że w tym samym roku zatrudniono 5382 osoby, to widoczny jest ogólny spadek liczby zatrudnionych, o czym już była mowa. Analiza przyczyn ustania zatrudnienia prowadzi do następujących ustaleń: z ogólnej liczby 3640 rozwiązanych stosunków pracy - 2406 nastąpiło z powodu wypowiedzenia przez pracodawcę, $297 \mathrm{w}$ drodze wypowiedzenia przez urzędnika, 106 z tytułu orzeczenia o niezdolności do pracy, 831 z tytułu przejścia na emeryturę. Na stan zatrudnienia wpłynęło także skorzystanie przez 208 urzędników (w blisko 100\% przez kobiety) z przejścia na urlopy wychowawcze. Ta statystyka zatrudnienia i zwolnień jest przyczyną dużej dyferencjacji długości stażu zatrudnienia w administracji: najliczniejsza grupa - 9576 urzędników - ma staż najdłuższy, bo co najmniej 30-letni, prawie o połowę mniejsza - 5205 osób - jest grupa urzędników o stażu 5-10 lat, a po niej o stażu 10-15 lat (4560) i 15-20 lat (4151), a następnie również dwie grupy stażowe: 20-25 lat (3657) i 25-30 lat (3550), wreszcie przedział stażowy 2-5 lat (1399) i najmniej liczna grupa - 927-osobowa - o stażu do 2 lat. Z powyższych analiz wynika, że grupy urzędników pod względem stażu pokrywają się zasadniczo z grupami wiekowymi, stąd też najliczniejszą grupą urzędników są najstarsi wiekiem, którzy swoją karierę zawodową zaczynali jeszcze w administracji państwa socjalistycznego, scentralizowanego i opartego na podstawach ideologicznych, a nie prawnych. Toteż oni sa najczęściej wskazywani jako kreujący negatywny obraz administracji, bo choć nabyli największą wprawę w wykonywaniu czynności biurowych, to są obciążeni nawykami, którymi nasiąknęli u początku swego 
zatrudnienia, kiedy kształtowały się ich postawy zawodowe, a zatem typowe dla władzy autorytarnej traktowanie obywatela jako petenta, a nie interesanta czy klienta usługi publicznej.

Jako ilustrację opisywanych procesów można podać przykład Urzędu Marszałkowskiego Dolnego Śląska ${ }^{23}$, w którym na koniec października 2016 r. było 1011 etatów, na których zatrudnionych było 1028 osób, co oznacza wzrost o $2 \%$ w stosunku do stanu na koniec 2015 r. Jak w pozostałych opisywanych dotąd analizach stanu kadr administracji publicznej, także i w tym urzędzie przeważają kobiety (761) nad mężczyznami (268), zaś ich kwalifikacje są w przeważającej liczbie wysokie (979 osób), przy 48 osobach z wykształceniem średnim i jedną z zawodowym. Struktura wiekowa zatrudnionych to: 506 osób w wieku 31-40 lat, 220 osób w wieku 41-50 lat, 122 osoby w wieku 20-30 lat i 121 osób w wieku 51-60 lat, wreszcie 60 osób liczy więcej niż 60 lat. W ciągu 2016 r. ogłoszono 71 naborów na 74 wolne stanowiska urzędnicze, w tym kierownicze urzędnicze, do końca października zakończono 42 nabory, wskazując 36 osób do zatrudnienia, do końca roku miało odbyć się jeszcze 29 naborów. Atrakcyjność zatrudnienia w urzędzie jest wyraźnie zależna od pozycji hierarchicznej stanowiska i jego zakresu czynności, bowiem na stanowisko Specjalisty w Dziale Gospodarki Wodno-Ściekowej w Wydziale Środowiska złożono rekordową liczbę 24 ofert, podczas gdy na stanowisko Głównego Specjalisty w Dziale Aplikacji w Wydziale Systemów Informatycznych nie złożono ani jednej ${ }^{24}$.

Dla porównania, w Dolnośląskim Urzędzie Wojewódzkim ${ }^{25}$ w 2016 r. ogłoszono 183 nabory, z czego 158 zakończono, 23 są w toku i 2 ogłoszone w grudniu. Ze 158 naborów wskazano do zatrudnienia 113 osób, ale $4 \mathrm{z}$ nich zrezygnowały $\mathrm{z}$ podjęcia zatrudnienia, w czterech przypadkach nabory anulowano ${ }^{26}, \mathrm{w}$ siedmiu przypadkach nikt nie złożył

${ }^{23} \mathrm{~W}$ przygotowaniu artykułu skorzystano z danych udostępnionych na wniosek w trybie przepisów ustawy o dostępie do informacji publicznej przez Departament Prawny i Kadr Urzędu Marszałkowskiego Województwa Dolnośląskiego.

${ }^{24} \mathrm{~W}$ trzech przypadkach złożono po jednej ofercie, w ośmiu po dwie, w trzech po trzy, w czterech po cztery, w trzech po pięć i po sześć, w pięciu po siedem, w jednym przypadku osiem ofert, w dwóch po dziewięć, w jednym dziesięć ofert, w dwóch po jedenaście, $w$ jednym dwanaście, w dwóch po trzynaście, $w$ jednym piętnaście, w jednym osiemnaście, a w jednym ogłoszeniu na dwa stanowiska łącznie złożono 21 ofert.

${ }^{25}$ Podczas przygotowania artykułu wykorzystano dane zamieszczone na stronie internetowej Dolnośląskiego Urzędu Wojewódzkiego bip.duw.pl/bip/praca-w-duw/ (dostęp: 6 XII 2016).

${ }^{26}$ Przepisy pragmatyki służby cywilnej nie przewidują instytucji anulowania naboru. 
oferty, a w czterech przypadkach zgłaszający się nie spełnili wymagań formalnych. Brak dostępu do protokołów z przeprowadzonego nabo$\mathrm{ru}^{27} \mathrm{~W}$ ogłoszeniu o wynikach naboru na stronie Biuletynu Informacji Publicznej Dolnośląskiego Urzędu Wojewódzkiego uniemożliwia ocenę frekwencyjności naborów.

\section{Podsumowanie}

W artykule przedstawiono prawne uwarunkowania zatrudnienia w każdym z sektorów administracji publicznej, a następnie przedstawiono dane statystyczne dotyczące ogólnego stanu zatrudnienia oraz stanu zatrudnienia w poszczególnych sektorach w skali państwa oraz województwa dolnośląskiego. Wykorzystano dane o charakterze demograficznym pozwalające ocenić strukturę pod względem płci, przedziałów wiekowych i kwalifikacji, a także dane o fluktuacji zatrudnienia. Ich odpowiednie zestawienia i analizy porównawcze ukazują stan kadr polskiej i dolnośląskiej administracji, który nie skłania do pozytywnych refleksji. Pomijając populistyczne opinie o jakoby nadmiernym zatrudnieniu i jego przerostach w poszczególnych urzędach i jednostkach organizacyjnych, kadry prezentują się jako nadmiernie sfeminizowane (rodzi to społeczną opinię, jakoby praca $\mathrm{w}$ urzędzie była bardziej właściwa dla kobiety niż mężczyzny), przestarzałe (dominują grupy zaawansowane wiekowo) i mało atrakcyjne jako propozycja zatrudnienia dla młodych absolwentów studiów wyższych.

Wstępna diagnoza przyczyn tego stanu to nie tylko warstwa socjologicznych uwarunkowań, o których była mowa, ale przede wszystkim warstwa normatywna regulacji prawa urzędniczego. Przepisy tego prawa nie pozwalają realizować jednolitej i kompleksowej polityki kadrowej, nieprawidłowe są regulacje dotyczące naboru na wolne stanowiska urzędnicze, a także wewnętrznych awansów zawodowych i systemu oceniania. Wreszcie regulacje płacowe nie stwarzają efektywnych instrumentów zachęty do zatrudnienia w administracji publicznej. Przepisy prawa urzędniczego przez swoje rozproszenie i niespójność nie prowadzą do stworzenia ekwiwalentnych systemów zatrudnienia w poszczególnych sektorach administracji. Wreszcie last but not least należy

${ }^{27}$ Zgodnie $\mathrm{z}$ art. 30 ust. 2 pkt 2 pragmatyki służby cywilnej w protokole podawana jest liczba nadesłanych ofert, w tym liczba niespełnionych wymogów formalnych. 
wskazać, że słabością regulacji prawa urzędniczego jest nadmierne ich uzależnienie od wpływów politycznych, mimo że art. 153 ust. 1 Konstytucji $\mathrm{RP}^{28}$ gwarantuje neutralność polityczną korpusu służby cywilnej.

\section{THE STAFF SITUATION OF PUBLIC ADMINISTRATION FROM THE REGIONAL AND NATIONAL PERSPECTIVE}

\section{Su m mary}

This paper tackles staff problems of contemporary public administration. It starts with an analysis of the dependence between the efficiency of administration and the efficiency of public servants in administration, whose efficiency depends on the level and quality of their qualifications. The analysis was carried out in three perspectives (i) with regard to the whole public administration of the State, (ii) with regard to the State and government central administration and (iii) with regard to regional public administration, on the example of the Lower Silesia region.

It was assumed that the quality of the staff in administration is related to and depends on the legislation regulating the recruitment for public administration offices. The relevant provisions determine the choices made in the recruitment process and the subsequent creation of career paths. However, unstable and poor legal provisions have a negative impact on the quality of public administration personnel, which is manifested in poor performance, high employment fluctuations and a diminishing interest among the younger generation in a career in public administration. This, in turn, may distort the natural generation exchange of administration staff in the future.

As can be seen from the statistical analysis conducted in respect of the numbers of public administration employees and the fluctuation among them, as well as the demographic structure examined with regard the gender, age and length of employment, the initially assumed hypothesis of the negative consequences of the inconsistent legislative policy governing the regulations of the public administration staff. The sociological picture illustrating the attitudes among the members of the society to public administration confirms the hypothesis of the poor condition of public administration and a loss in confidence in its activities or actions. The main reason for the current situation is that the constitutional principle of the neutrality of civil servants is realised only by orders that prohibit combining civil service with political activity, but do not limit or reduce the strong and direct influence exercised by political parties on the legal regulations within public civil service or the policies of appointing candidates to key administrative positions in (not only government) offices.

Keywords: public administration staff - recruitment to public administration posts demographic structure of the public administration staff - staff turnover in public administration - law on public administration

\footnotetext{
${ }^{28}$ Konstytucja Rzeczypospolitej Polskiej z dnia 2 IV 1997 r. (Dz.U. Nr 78, poz. 483 ze zm.).
} 